\title{
THE OPEN FUTURE, FREE WILL AND DIVINE ASSURANCE: RESPONDING TO THREE COMMON OBJECTIONS TO THE OPEN VIEW
}

\author{
GREGORY A. BOYD
}

\begin{abstract}
In this essay I respond to three of the most forceful objections to the open view of the future. It is argued that a) open view advocates must deny bivalence; b) the open view offers no theodicy advantages over classical theism; and c) the open view can't assure believers that God can work all things to the better (Rom. 8:28). I argue that the first objection is premised on an inadequate assessment of future tensed propositions, the second is rooted in an inadequate assessment of free will, and the third is grounded in an inadequate assessment of God's intelligence.
\end{abstract}

In this essay I'll address three of the most forceful and most frequently voiced objections to open theism (or, as I prefer, 'the open view of the future', which I will henceforth abbreviate simply as 'the open view'). The first objection is that, to render their view coherent, advocates of the open view must accept one or the other of two strongly counterintuitive and otherwise problematic conclusions: they must either accept (i) that bivalence doesn't apply to propositions about future free actions, or (ii) that the truth value of such propositions is unknowable to God. The second objection I'll address is that the open view offers no advantage for resolving the problem of evil over the view that God possesses exhaustively definite foreknowledge (EDF), for denying that God eternally foreknew an evil deed leaves unexplained why God didn't intervene to prevent the deed once God saw it was inevitable, or at least highly probable. And the third objection I'll consider is the frequently voiced claim that, if God doesn't foreknow all that will come to pass in the future, God cannot assure believers that God can bring good out of evil and work all things together for the better (Rom. 8:28). It is rather argued that the open view must accept that our suffering may be completely outside God's purposes and therefore gratuitous. 
In what follows I shall argue that the first two objections are grounded in oversights regarding the logic of the future and of free will, while the last objection is grounded in a limited view of God.

\section{THE THREE CATEGORIES OF FUTURE TENSED PROPOSITIONS}

To begin, the objection that open view advocates must either deny bivalence or accept that certain truths are impossible for God to know is grounded in the traditional conviction that omniscience implies that God's knowledge of the future must be expressed exhaustively in terms of what either will or will not come to pass. The basic line of reasoning behind this conviction is as follows.

P1: All propositions asserting factual claims are either true or false (bivalence).

P2: Being omniscient, God knows the truth value of all meaningful propositions.

P3: The future can be exhaustively described in terms of what either will or will not come to pass.

C: Therefore, God foreknows the future exhaustively in terms of what either will or will not come to pass. In other words, God possesses EDF.

The argument is formally valid. Accordingly, those who deny the conclusion (C) must deny one or more of the premises. Some advocates of the open view deny (P1) and instead argue that propositions expressing future free actions are neither true nor false until the free agent renders them true or false by their free decision. Opponents point out that, among other problems, denying bivalence to propositions about future free actions is a drastic and strongly counter-intuitive strategy. Other advocates of the open view attempt to avoid (C) by denying (P2), arguing instead that, while propositions about future free actions are indeed either true or false, this truth value is logically impossible to know, even for God. Opponents point out that, among other problems, the postulation of propositions whose truth value cannot be known seems to undermine the very definition of omniscience.

Whether or not one considers these objections to be decisive, I contend that there is no reason for advocates of the open view to embrace either of these questionable strategies. I submit that the real flaw in the above-mentioned argument resides not in (P1) or in (P2), but 
in (P3). The traditional assumption that the future can be exhaustively expressed in terms of what will and will not come to pass overlooks an entire category of future tensed propositions whose truth value an omniscient God must know. It may be the case that (i) a future event $E$ will certainly come to pass, and it may be the case that (ii) a future event $E$ will certainly not come to pass. What was overlooked, however, is that it may also be the case that (iii) a future event $E$ might and might not come to pass, in which case it would be false both that $E$ will certainly come to pass and that $E$ will certainly not come to pass.

So far as I can discern, the primary reason for this oversight was that it has been customarily assumed that propositions such as ' $E$ will certainly come to pass' are the logical contradictory of propositions such as ' $E$ will certainly not come to pass'. If they are indeed contradictory, they exhaust all the possibilities. Hence, one of the propositions must be true and the other false. From this it followed that propositions asserting what will and will not certainly come to pass exhaust the field of meaningful propositions about the future whose truth value an omniscient God must know. Hence God must possess EDF.

Against this, I contend that the contradictory of ' $E$ will certainly come to pass' is not ' $E$ will certainly not come to pass', but rather, 'It is not the case that $E$ will certainly come to pass'. This logically entails that ' $E$ might not come to pass'. So too, the contradictory of ' $E$ will certainly not come to pass' is not ' $E$ will certainly come to pass', but rather, 'It is not the case that $E$ will certainly come to pass'. This logically implies that ' $E$ might come to pass'.

If we apply the Square of Opposition to this assessment (see the Appendix), it becomes apparent that ' $E$ will certainly come to pass' and ' $E$ will certainly not come to pass' are contraries, not contradictories. As such, both cannot be true, but both may be false. So too, it becomes clear that ' $E$ might come to pass' and ' $E$ might not come to pass' are subcontraries, not contradictories. As such, both cannot be false, but both may be true. And in cases in which 'might' and 'might not' propositions are conjointly true, both of their logical contradictories - viz. ' $E$ will certainly come to pass' and ' $E$ will certainly not come to pass' - are necessarily false.

If this assessment is correct, we must accept that there are three, not merely two, categories of meaningful propositions about the future whose truth value an omniscient God must know. An adequate mapping of propositions expressing possible future state of affairs must include: 
(i) propositions asserting a determinate affirmation - viz. 'will certainly occur';

(ii) propositions asserting a determinate negation - viz. 'will certainly not occur'; and

(iii) propositions asserting an indeterminate affirmation and negation viz. 'might and might not occur'.

Moreover, if this assessment is correct, it means the traditional view of divine foreknowledge is anchored in the fact that an entire domain of logically possible worlds that God could have created was overlooked: namely, all logically possible worlds that include, to one degree or another, an indeterminate future. The distinct claim of open view advocates is that, not only is a world with an indeterminate future logically possible, but we have compelling biblical, philosophical and experiential reasons to believe that this is, in fact, the kind of world God decided to create.

In this light, I trust it is clear why open view advocates need not deny that bivalence applies to future tensed propositions about future free actions. We simply need to apply bivalence to three categories of future tensed propositions rather than to two. Open view advocates can thus affirm that God knows the truth value of all meaningful propositions, including propositions about future free actions. The only distinct claim of open view advocates should be that propositions asserting what might and might not come to pass can be conjointly true, in which case corresponding propositions asserting what will and will not come to pass must be conjointly false.

\section{THE IRREVOCABILITY OF FREE WILL}

The second common objection to the open view that I'd like to address concerns the allegation that the open view offers no advantage in terms of resolving the problem of evil compared to the view that ascribes EDF to God. Even if we grant that God didn't eternally foreknow a particular evil deed would take place, the argument goes, we yet have to explain why God didn't intervene to prevent the deed once God saw it was inevitable, or at least saw that it was highly probable. And the latter problem, it is plausibly argued, is as great as the former. What real difference does it make whether God decided to allow Hitler to embark on the Final Solution an eternity before it took place or merely a year or a week before it was certain to take place? So long as we believe God has the power 
to intervene, which seems to be implied in omnipotence, it makes no difference when God makes the decision not to intervene to prevent an evil.

I shall argue that this objection is rooted in an inadequate assessment of the logic of libertarian free will that leads to the mistaken assumption that an all-powerful God must be able to prevent any event God would like to prevent.

While there is a multitude of contested philosophical issues surrounding the concept and conditions of (libertarian) free will, for our present purposes the following minimalistic definition will suffice: Agents possess free will if and only if they have the capacity to resolve, by their own volition, two or more possible courses of action into one actual course of action. Libertarian free will, in other words, refers to an agent's God-given self-determining capacity to actualize this possible course of action or that possible course of action.

If this basic understanding of free will is accepted, I believe we can begin to understand how an all-powerful God would be unable to prevent events God wished could be prevented. Suppose God has endowed a particular agent $(\mathrm{x})$ with the self-determining capacity to choose to go this way or that way - this way representing a way God approves of and that way representing a way God disapproves of. If God were to then prevent agent $(\mathrm{x})$ from going that way because God disapproved of it, it would then become clear that, as a matter of fact, God didn't endow agent $(\mathrm{x})$ with the self-determining capacity to choose to go this way or that way. Conversely, if God truly endowed agent (x) with the selfdetermining capacity to choose to go this way or that way, God must, by definition, allow agent $(\mathrm{x})$ to go that way, if agent $(\mathrm{x})$ so chooses.

Another way of stating this is to say that free will is, by definition, irrevocable. The concept of God preventing an agent from freely going that way once God has endowed the agent with the self-determining capacity to choose to go this way or that way is self-contradictory, no different from the concept of a round triangle or married bachelor. And just as God's omnipotence isn't limited by God's inability to make a round triangle or a married bachelor, so too, I contend, God's omnipotence isn't limited by God's inability to revoke free will once God's given it. Moreover, it's important to realize that in the initial decision to give agents free will, God is granting them the capacity to freely resolve every possible course of action they might face in the future, for as we'll see below, an omniscient God would know every possible decision the 
agent might make when God gives them scope of free will he gives them. The irrevocability of free will, therefore, must apply to every possible decision that falls within the scope of the God-given free will of an agent throughout the duration of that agent's life.

If this much is accepted, it seems to me that the open view can be shown to offer a distinct advantage explaining evil over and against all traditional views that hold that God merely chooses not to intervene to prevent each particular episode of evil. For if God merely chooses to not prevent a particular episode of evil, God must in some sense want that particular episode of evil to take place, at least more than God wants to prevent it. And since God is all-good, every decision God makes, including the decision to not prevent a particular episode of evil, must be good. This perspective thus requires us to accept that there is a specific good divine reason behind each and every episode of evil throughout history. In my opinion, this constitutes the most challenging aspect of the classical theistic solution to the problem of evil. If we accept the essential irrevocability of free will, however, we no longer have to claim that God merely chooses not to prevent evil. We would instead claim that, given the kind of world God decided to create - viz. a world populated with free agents - God is unable to unilaterally intervene to prevent freely chosen evil, as much as God would like to.

While we may specify reasons as to why God decided to create a cosmos that was populated with free agents, this view does not require us to suppose there is a specific good divine reason behind episodes of evil. Rather, the ultimate reason why any particular episode of evil came to pass lies in the agent who chose to bring it about, not in God. Hence, in the face of any particular evil, it would make sense in this view to ask: 'Why did God decide to create a cosmos populated with free agents?', a question that has a plausible answer, in my opinion. And it would make sense in this view to ask: 'Why did this particular agent bring about this particular evil?' But it would not make sense in this view to ask: 'Why did God allow this agent to bring about this particular evil?' For this irrevocable permission is already implied in asserting that God endowed the agent with free will. Hence, the ultimate reason for each episode of evil, in this view, ends with the agent(s) who chose to carry it out. God had no reason for whatever evil an agent freely brings about: God simply could not stop it, given that he decided to create this kind of world populated with these kinds of agents. And that great advantage of this perspective is that it completely relieves us of the torturous burden 
of positing a specific good divine reason behind every specific episode in history.

\section{DIVINE ASSURANCE AND THE OPEN FUTURE}

The third and final commonly raised objection against the open view also concerns God's inability to intervene to prevent evils in the open view. It is frequently argued that a God who faced a partly open future could not promise believers that there is a divine purpose for their suffering or that God can ultimately bring good out of evil (Rom 8:28). Indeed, some conservative critics have argued that the open view posits a limited, passive, hand-wringing God' who can do little more than hope for the best. '[W] hat is lost in open theism, Bruce Ware contends,

... is the Christian's confidence in God ... . When we are told that God ... can only guess what much of the future will bring ... [and] constantly sees his beliefs about the future proved wrong by what in fact transpires ... Can a believer know that God will triumph in the future just as he has promised he will? (2000: 216)

Opponents of the open view have done an excellent job preventing people from seriously considering this view by installing fear in them with frequently voiced terrifying claims such as this. Most people have an understandable desire, if not need, to believe that their suffering and/or the suffering of loved ones is not simply random and gratuitous, but rather serves an ultimate, good divine purpose. They thus long for the assurance that God can work all things together and bring good out of evil, and any view that can't deliver on these promises is simply a nonstarter.

I think open view advocates must frankly admit that our view does in fact entail that suffering happens randomly. Once one denies that there is a specific divine reason behind each specific episode of suffering that comes to pass and instead affirms that the final reason behind any episode of suffering resides in the agent(s) who carried it out, this conclusion is unavoidable. At the same time, I do not believe that acknowledging this entails that God cannot promise to bring good out of evil or to have an ultimate purpose for all suffering. Indeed, I will now argue that, so long as we are confident that God possesses unlimited intelligence, the open view can offer believers the same level of assurance as the traditional view that ascribes EDF to God and believes this gives God a providential advantage. 
I submit that the reason why so many assume God is less able to have a plan to bring good out of evil if the future is partly comprised of possibilities than if the future is exhaustively settled is because they project their own human limitations onto God. We humans are obviously less able to effectively prepare for a multitude of possible future events than we are a single future event that is certain, and the reason is that we only have a finite amount of intelligence to anticipate the future with. Hence, the more possibilities we have to anticipate, the thinner we have to spread our intelligence to anticipate each of them. This is why, for example, playing a formidable opponent in an important game of chess is more stressful than (say) working on an assembly line where a person knows exactly what is coming.

If we affirm that God has unlimited intelligence, however, God would not have to spread thin God's intelligence to cover any number of possibilities. A God of unlimited intelligence could attend to each and every one of a gazillion possibilities (to the gazillionth power!) as though each and every one was the only possibility - viz. as though each was an absolute certainty. There is therefore no functional difference between the way a God of unlimited intelligence would anticipate a future possibility and a future certainty. There is therefore no functional difference between the way the open view of God anticipates each and every one of the possible future story lines that comprise the open future and the way the traditional God who possesses EDF anticipates the single, exhaustively settled, future story line. To put it in other words, since God's intelligence has no limit, it is as though all of God's attention is on each possible story line - exactly the same as it would be if each possible story line was the only possible story line, viz. as if each was the one and only exhaustively settled story line of the traditional view.

This means that the advocate of the open view can affirm as robustly as any defender of the traditional view that, whatever comes to past, God has been preparing a plan, from the foundation of the world, as to how God would respond to bring good out of this event, however evil the event itself may be. It's just that the open view advocate is confident enough in God's intelligence to affirm that God didn't need to foreknow this event as a certainty to prepare for it as if it were a certainty. Any number of other possible events might have taken place, and if they had, the open view advocate would be claiming the exact same thing about them! 
We might say that a God of unlimited intelligence doesn't need to have a specific eternal purpose for specific events in order to bring an equally specific eternally prepared purpose to these events. Hence, whereas the traditional view has always affirmed that everything happens for a good divine purpose, open view advocates can affirm that everything happens with a good divine purpose. And the good purpose God brings to events is just as perfect as it would have been had God specifically allowed that event for this good purpose. The open view advocate can thus affirm the same divine assurance as classical theists, but without the terrible burden of claiming that God specifically allowed, or ordained, evil events for a good divine purpose.

I trust it's apparent why only a God of limited intelligence would lose a providential advantage by virtue of knowing a future that included possibilities as opposed to a future that was exhaustively settled. When Bruce Ware asserts that a God who faced a future comprised of possibilities would be a 'limited, passive, hand-wringing God' who could do little more than 'guess what much of the future will bring, he is unwittingly tipping his hand to his own limited view of God's intelligence while telling us nothing about the actual view of God that open view advocates embrace (or at least ought to embrace). And given his and others' limited view of God, it's hardly surprising that Bruce Ware and others continually express great fear when they consider the consequences of God facing a future that isn't exhaustively settled ahead of time.

If we simply remain confident in God's unlimited intelligence, the last thing we can ever imagine God doing is wringing his hands and making guesses in the face of a partly open future.

\section{APPENDIX}

\section{THE HEXAGONIC LOGIC OF AN OPEN FUTURE ${ }^{1}$}

Whereas the Aristotelian Square assigns no primitive operator to a future indeterminate state of affairs, thus exemplifying a prejudice toward determinism, we will use $\mathrm{Q}$ as a primitive operator meaning, 'It is indeterminately the case that ... alongside primitive operator $Z$ meaning,

\footnotetext{
${ }^{1}$ From G. Boyd, T. Belt and A. Rhodes, 'The Hexagon of Opposition: Thinking Outside the Aristotelian Box' (unpublished manuscript).
} 
'It is determinately the case that ...' We will thus revise the Square in such a way that $\mathrm{Q}$ will be granted the same logical status as $\mathrm{Z}$.

Using $\mathrm{Q}$ and $\mathrm{Z}$ as defined, we arrive at:

$Z(S)=$ It is determinately the case that state of affairs $S$ occur (' $S$ will obtain')

$Z(\sim S)=$ It is determinately the case that state of affairs not- $S$ occur (' $S$ will not obtain')

$\mathrm{Q}(S)=$ It is indeterminately the case that state of affairs $S$ occur ('S might and might not obtain')

Each of these propositions affirms a distinct metaphysical possibility concerning any possible future state of affairs. These possibilities are jointly exhaustive and mutually exclusive. As jointly exhaustive, at least one must be true for any meaningful future tense proposition. Thus we arrive at our first theorem:

- $(S)[(\mathrm{Z}(S)$ v Z $(\sim S) \vee \mathrm{Q}(S)]$.

As mutually exclusive, if any one is true, then the other two must be false, giving us three additional theorems:

$-\mathrm{Z}(S) \Leftrightarrow \sim \mathrm{Z}(\sim S) \wedge \sim \mathrm{Q}(S)$

$-\mathrm{Z}(\sim S) \Leftrightarrow \sim \mathrm{Z}(S) \wedge \sim \mathrm{Q}(S)$

$-\mathrm{Q}(S) \Leftrightarrow \sim \mathrm{Z}(S) \wedge \sim \mathrm{Z}(\sim S)$

Because no two can be true at the same time, while any two can be false at the same time, these three possibilities are related as contraries, which we can represent by the following Triangle of Contrary Relations.

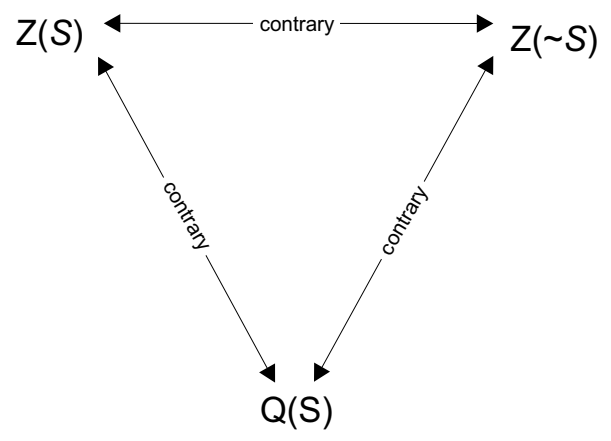

Fig. 1: Triangle of Contrary Relations 
This Triangle of Contrary Relations generates a Triangle of Subcontrary Relations when we associate each possibility with its the contradictory. Consider first $Z(S)$ ('It is determinately the case that state of affairs $S$ obtain'). The contradictory of $Z(S)$ is, of course, $\sim Z(S)$ ('It is not determinately the case that state of affairs $S$ obtain') and can be illustrated as follows:

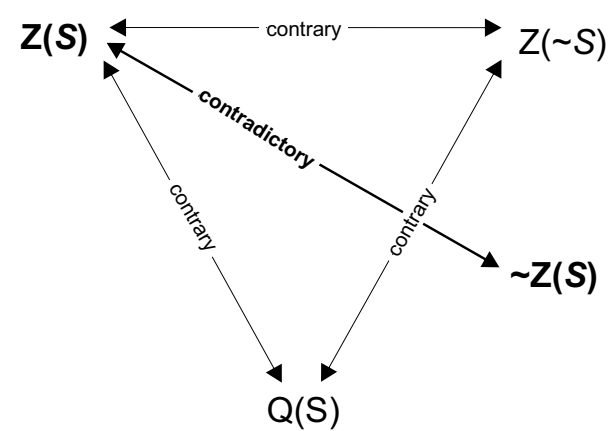

Fig. 2: Contradictory of $\mathrm{Z}(\mathrm{S})$

The contradictory of $Z(\sim S)$ ('It is determinately the case that state of affairs not-S obtain') is $\sim Z(\sim S)$ ('It is not determinately the case that state of affairs not-S obtain') which we locate opposite its contradictory:

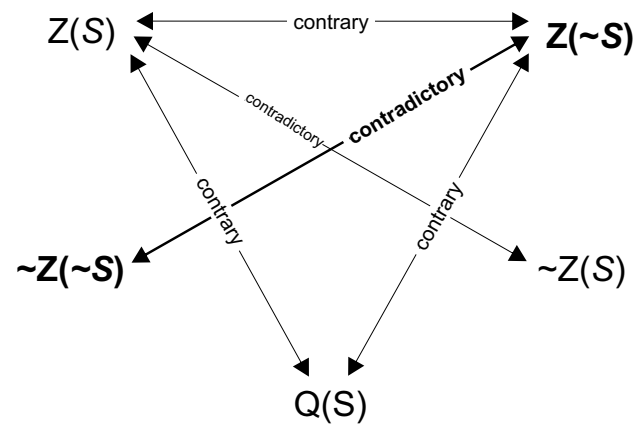

Fig. 3: Contradictory of $Z(\sim S)$

Lastly, the contradictory of $Q(S)$ ('It is indeterminately the case that state of affairs $S$ obtain') is $\sim Q(S)$ ('It is not indeterminately the case that state of affairs $S$ obtain'), illustrated as follows: 


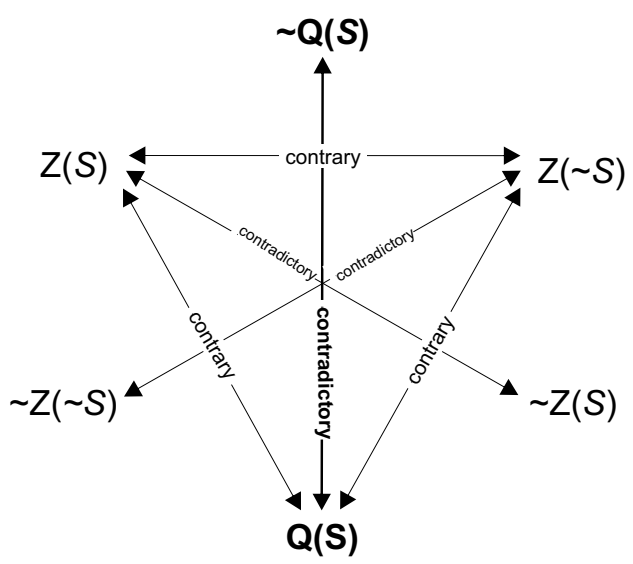

Fig. 4: Contradictory of $\mathrm{Q}(\mathrm{S})$

Note that the first two propositions above, $Z(S)$ and $Z(\sim S)$ ('will' and 'will not') and their contradictories are explicit on the traditional Square. But the third proposition, $Q(S)$ ('might and might not') and its contradictory $\sim Q(S)$ have now been made explicit.

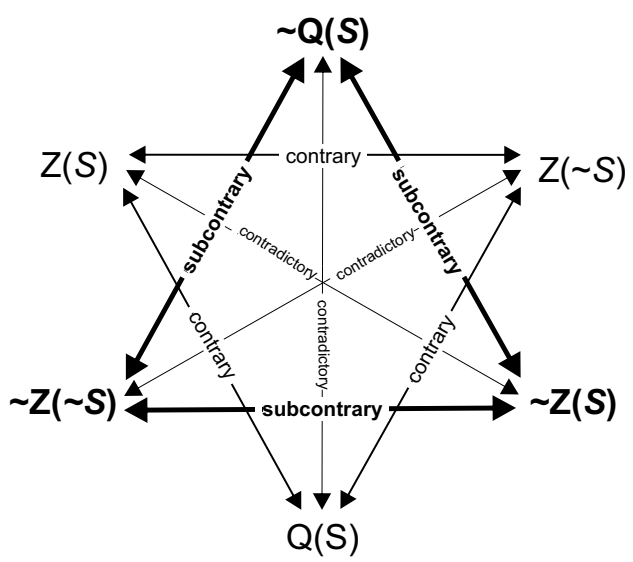

Fig. 5: Triangle of Subcontrary Relations

Now let's consider how the contradictories $\sim \mathrm{Z}(S), \sim \mathrm{Z}(\sim S)$ and $\sim \mathrm{Q}(S)$ are related to each other. Consider the pair $\sim Z(S)$ and $\sim Z(\sim S)$. Since $\mathrm{Q}(S)$ entails both $\sim \mathrm{Z}(S)$ and $\sim \mathrm{Z}(\sim S)$ (by Theorem IV), it is clear that they are conjointly true when $\mathrm{Q}(S)$ is true. It is equally clear that $\sim \mathrm{Z}(S)$ and $\sim \mathrm{Z}(\sim S)$ cannot be conjointly false. For if $\sim \mathrm{Z}(S)$ is false, then $\mathrm{Z}(\mathrm{S})$ 
is true, and if $\sim \mathrm{Z}(\sim S)$ is false, then $\mathrm{Z}(\sim S)$ is true. But $\mathrm{Z}(S)$ and $\mathrm{Z}(\sim S)$ cannot be conjointly true (by Theorems II and III), so $\sim \mathrm{Z}(S)$ and $\sim \mathrm{Z}(\sim S)$ cannot be conjointly false. The same results obtain mutatis mutandis for the other pairs, $(\sim \mathrm{Z}(S)$ and $\sim \mathrm{Q}(S) ; \sim \mathrm{Z}(\sim S)$ and $\sim \mathrm{Q}(S))$. So, for each pair, it is possible that both be true and not possible that both be false, which means that they are subcontraries. We thus arrive at a Triangle of Subcontraries overlapping with the Triangle of Contrary Relations.

Thus far we have considered contrary, contradictory, and subcontrary relations. There remains one more logical relation to consider, namely, subaltern relations, which run outward from $Z(S), Z(\sim S)$, and $Q(S)$. We already know from the Square that $\sim Z(\sim S)$ is the subaltern of $Z(S)$. Thus, if $Z(S)$ ('will') is true, the subaltern $\sim Z(\sim S)$ ('might') is necessarily true. The same now applies to the relationship between $Z(S)$ and the adjacent $\sim Q(S)$ ("not "might and might not"). If $Z(S)$ is true, $\sim Q(S)$ must be true. Likewise, if $Z(\sim S)$ ('will not') is true, the subaltern $\sim Z(S)$ ('might not') is also true. The same subaltern relationship exists between $Z(\sim S)$ and $\sim Q(S)$. If $Z(\sim S)$ is true, $\sim Q(S)$ must be true. Lastly, $Q(S)$ ('might and might not') also has subaltern relations with the adjacent propositions. If $Q(S)$ ('might and might not') is true, both subalterns $\sim Z(\sim S)$ ('might') and $\sim Z(S)$ ('might not') are true.

As figure 7 illustrates, the subaltern relations run from each of the three propositions forming our Triangle of Contrary Relations to each of the propositions forming the Triangle of Subcontrary Relations, completing a Hexagon of Subaltern Relations:

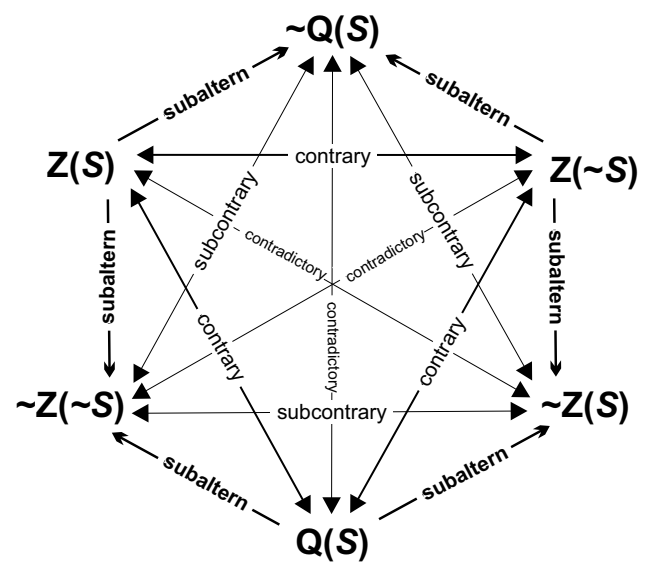

Fig. 6: Hexagon of Subaltern Relations 
Note that the traditional Square of Opposition is still present in the Hexagon. We have simply enlarged and completed it. Indeed, one should notice that in completing the traditional Square we have uncovered two other intersecting Squares of Opposition, each exhibiting different truth functions but preserving the same logical relations. The traditional Square of Opposition is composed of contraries $Z(S)$ and $Z(\sim S)$ and subcontraries $\sim Z(\sim S)$ and $\sim Z(S)$. A second Square is composed of contraries $\mathrm{Z}(S)$ and $\mathrm{Q}(S)$ and subcontraries $\sim \mathrm{Z}(S)$ and $\sim \mathrm{Q}(S)$. A third Square is composed of $\mathrm{Z}(\sim S)$ and $\mathrm{Q}(S)$ and subcontraries $\sim \mathrm{Q}(S)$ and $\sim \mathrm{Z}(\sim S)$. The three squares may be highlighted as follows:
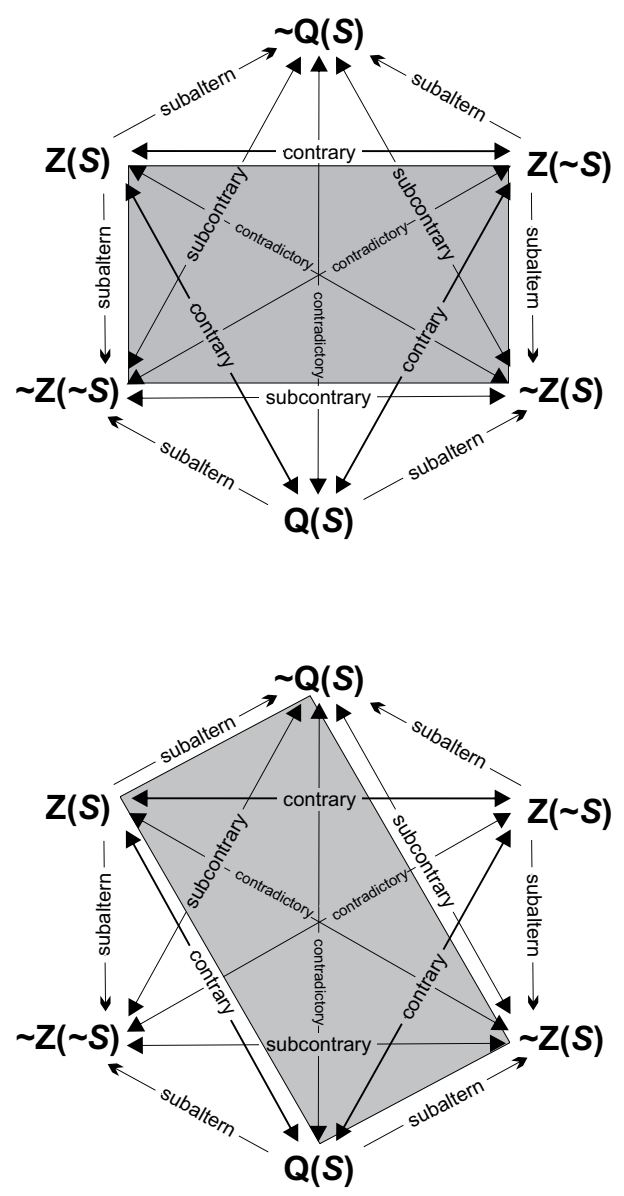


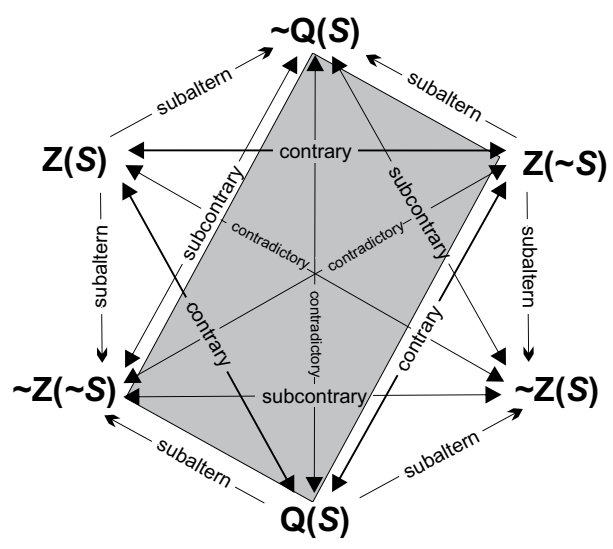

Fig. 7: Three Squares of Opposition

\section{BIBLIOGRAPHY}

Ascol, Tom K. 2001. 'Pastoral Implications of Open Theism', in Douglas Wilson (ed.), Bound Only Once: The Future of Open Theism (Moscow, ID: Canon), pp. 173-190

Beilby, James K. \& Paul R. Eddy (eds). 2001. Divine Foreknowledge: Four Views (Downers Grove: InterVarsity)

Boyd, Gregory. 2001a. 'The Open-Theism View', in James K. Beilby \& Paul R. Eddy (eds), Divine Foreknowledge: Four Views (Downers Grove: InterVarsity), pp. 13-47

Boyd, Gregory. 2001b. Satan and the Problem of Evil: Constructing a Trinitarian Warfare Theodicy (Downers Grove: InterVarsity)

Boyd, Gregory. 2003. 'Neo-Molinism and the Infinite Intelligence of God', Philosophia Christi, 5/1: 187-204

Boyd, Gregory. 2009a. 'Evolution as Cosmic Warfare: Satan and the Problem of "Natural Evil"', in Thomas Jay Oord (ed.), Creation Made Free: Open Theology Engaging Science (Eugene, OR: Pickwick), pp. 125-145

Boyd, Gregory. 2009b. 'Two Ancient (and Modern) Motivations For Ascribing Exhaustively Definite Foreknowledge to God: A Historic Overview and Critical Assessment', Religious Studies, 46/1 (March 2010): 41-59

Boyd, Gregory \& T. Belt and A. Rhodes, 'The Hexagon of Opposition: Thinking Outside the Aristotelian Box' (unpublished manuscript)

Erickson, Millard J. 2003. What Does God Know and When Does He Know It?: The Current Controversy Over Divine Foreknowledge (Grand Rapids: Zondervan) 
Frame, John M. 2001. No Other God: A Response to Open Theism (Phillipsburg, NJ: P\&R Publishing)

Geisler, Norman L. 1997. Creating God in the Image of Man? The New 'Open' View of God - Neotheism's Dangerous Drift (Minneapolis: Bethany)

Geisler, Norman L. \& H Wayne House. 2001. The Battle For God: Responding to the Challenge of Neo-Theism (Grand Rapids: Kregel)

Huffman, Douglas S. \& Eric L. Johnson (eds). 2002. God Under Fire: Modern Scholarship Reinvents God (Grand Rapids: Zondervan)

Oord, Thomas Jay (ed.). 2009. Creation Made Free: Open Theology Engaging Science (Eugene, OR: Pickwick)

Piper, John, Justin Taylor \& Paul Kjoss Helseth. 2003. Beyond the Bounds: Open Theism and the Undermining of Biblical Christianity (Wheaton, IL: Crossway)

Roy, Steven C. 2006. How Much Does God Foreknow? A Comprehensive Biblical Study (Downers Grove: IVP Academic)

Sanders, John. 2007. The God Who Risks: A Theology of Divine Providence, 2nd ed. (Downers Grove: IVP Academic)

Ware, Bruce A. 2000. God's Lesser Glory: The Diminished God of Open Theism (Wheaton, IL: Crossway Books)

Wilson, Douglas (ed.). 2001. Bound Only Once: The Future of Open Theism (Moscow, ID: Canon) 